\title{
Isolation of epiphytic yeasts from Eugenia dysenterica DC. fruits and evaluation of their antimicrobial activity against phytopathogenic fungi
}

\section{Isolamento de leveduras epifíticas de frutos de Eugenia dysenterica DC. e avaliação de atividade antimicrobiana contra fungos fitopatogênicos}

\author{
Camilla Martins Malta' (D) | Eskálath Morganna Silva Ferreiral (D) | \\ Thamar Holanda da Silva' (1) | Divina Anne Batista Oliveiral (1) | Filipe Miguel Pereira da Silval (1) \\ Juliana Fonseca Moreira da Silval (D) | Raphael Sanzio Pimental (D) \\ Universidade Federal do Tocantins. Palmas, Tocantins, Brasil
}

\begin{abstract}
Plants commonly interact with microorganisms that may influence their physiology and performance. Epiphytic yeasts are microorganisms that can be found in the phylosphere, in significantly larger numbers in fruits than in other plant tissues due to their higher nutritional content. The present study aimed to contribute to knowledge of epiphytic yeasts associated with Eugenia dysenterica DC. fruits and to evaluate their antimicrobial activity against phytopathogens. E. dysenterica fruits were collected, washed in saline solution, and sonicated. Each fruit solution was plated in three Petri dishes with NYDA medium. Yeast identification was performed through morphological and physiological criteria, and richness evaluation was performed using the Jackknife 1 estimator. All isolated yeasts were tested for diffusible substances against three phytopathogenic fungi. Only four of 42 isolates were inhibited sporulation of Aspergillus parasiticus, but none was able to inhibit or diminish mycelium growth of any tested phytopathogen. The present study contributes to the characterization of the $E$. dysenterica microbiome, presenting the first report of in vitro A. parasiticus sporulation inhibition by epiphytic yeasts and suggesting their promising use in biological control of this phytopathogen.
\end{abstract}

Keywords: Antagonist yeasts. Biological control. Aspergillus parasiticus. Sporulation inhibition.

Resumo: As plantas interagem com microrganismos que podem influenciar na fisiologia e no desempenho das espécies. Leveduras epifíticas são microrganismos encontrados no filosfera, com maiores populações em frutos do que em outros tecidos vegetais, por haver maior disponibilidade de conteúdo nutricional. Os objetivos deste estudo foram contribuir para o conhecimento sobre leveduras epifíticas associadas com frutos de Eugenia dysenterica DC. e avaliar sua atividade antimicrobiana contra fitopatógenos. Os frutos foram coletados, lavados em solução salina e sonicados. Uma alíquota de cada solução obtida foi semeada em triplicata em placas de Petri contendo meio NYDA. Fez-se a identificação das leveduras por critérios morfofisiológicos e a avaliação da riqueza de espécies por estimador de riqueza Jackknife 1. Todas as leveduras isoladas foram testadas quanto à produção de substâncias difusíveis contra três fungos fitopatogênicos. Somente quatro dos 42 isolados foram capazes de inibir a esporulação de Aspergillus parasiticus, mas nenhum inibiu ou reduziu o crescimento micelial de fitopatógenos avaliados. Este estudo contribuiu para a caracterização do microbioma associado a $E$. dysenterica e consistiu na primeira observação da inibição in vitro da esporulação de A. parasiticus por leveduras epifíticas, o que sugere ser um método promissor para aplicação como controle biológico deste fitopatógeno.

Palavras-chave: Leveduras antagonistas. Controle biológico. Aspergillus parasiticus. Inibição da esporulação.

MALTA, C. M., E. M. S. FERREIRA, T. H. SILVA, D. A. B. OliVEIRA, F. M. P. SILVA, J. F. M. SILVA \& R. S. PIMENTA, 2019. Isolation of epiphytic yeasts from Eugenia dysenterica DC. fruits and evaluation of their antimicrobial activity against phytopathogenic fungi. Boletim do Museu Paraense Emílio Goeldi. Ciências Naturais 14(2): 223-231.

Autor para correspondência: Raphael Sanzio Pimenta. Universidade Federal do Tocantins. Laboratório de Microbiologia Geral e Aplicada. ALC NO14 - Campus Universitário. Av. NS 15, Bloco II, Sala 5. Palmas, TO, Brasil. CEP 77001-090 (pimentars@uft.edu.br).

Recebido em 01/11/2018

Aprovado em 22/01/2019

Responsabilidade editorial: Fernando da Silva Carvalho Filho
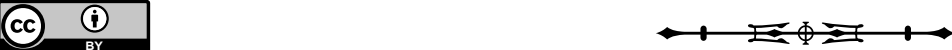


\section{INTRODUCTION}

Plant-associated microorganisms have been shown to affect significantly their hosts' physiology and environmental adaptation, suggesting that evolution and ecology of plants and animals with their associated microorganisms can be understood as a holobiont organism context (Agler et al., 2016). Specialized nutritional communities found on the surface of living plants, particularly on leaves, are known as epiphytes (Hongsanan et al., 2016).

Fungal epiphytes are a polyphyletic group that colonize all known plant species and have a worldwide distribution (Schoch et al., 2009; Wu et al., 2011; Hyde et al., 2013; Hongsanan et al., 2014, 2015a, 2015b, 2015c; Li et al., 2016). Many fungal epiphytes are obligate parasites, others are opportunists or symbionts (Wu et al., 2011; Hongsanan et al., 2015a), and some are saprobes (Chomnunti et al., 2014; Hongsanan et al., 2015c). On the other hand, plants are commonly engaged in neutral or mutualistic interactions with epiphytes that may have a positive contribution for their hosts (PartidaMartínez \& Heil, 2011), such as influencing plants growth (Ludwig-Müller, 2015; Panke-Buisse et al., 2015; Agler et al., 2016), water economy of host plants (Stanton et al., 2014), producing bioactive substances used by hosts as protective antifungal agents (Newman \& Cragg, 2015), and conferring host plant resistance to insects and herbivores (Hansen \& Moran, 2014).

However, there is a hypothesis that the interaction fungi-host plant must be balanced between the virulence of the fungi and the plant defences. If such a balance shifts, through plant defence deficiency or fungi virulence increase, a symptomatic manifestation may arise (PartidaMartínez \& Heil, 2011).

The search for new microorganisms with potential use in biological control has become a priority worldwide (Berg et al., 2014; Mahamuni et al., 2017; van Lenteren et al., 2018). Recent studies from tropical forests, savannas, and other biomes suggest that fungal diversity is greater in the tropics than in other regions (Nisa et al., 2015).
The tropical environment can provide to these organisms' good conditions for growth and reproduction. Furthermore, a rich diversity of tropical plants can provide many nutrients, especially in their fruits to furnish excellent habitats for many microorganism communities and populations, including yeasts (Barriga et al., 2014; Grondin et al., 2015).

One of the most important steps in biological control research is the identification of species to be used as biocontrol agents and the role of antagonistic microorganisms in pathogen control (Köhl et al., 2011). Microorganisms (bacteria, yeasts, and filamentous fungi) naturally present on fruits and plant surfaces, may inhibit the growth of other microorganisms, including plant pathogenic fungi (Sharma \& Awasthi, 2010). Harvested fruits, leafs, nuts, grains, and other vegetable foods contaminated with pathogens have reduced shelf-life, quality and can be dangerous for human consumption. Products that are harvested and consumed fresh can be more readily decayed by fungal or bacterial pathogens. However, certain beneficial microorganisms can be used as biological control agents against postharvest diseases (Lugtenberg et al., 2017). A good understanding of the relationships between pathogens, antagonistic microorganisms, fruits, plants and the environment is essential for the successful implementation of biological control in the postharvest phase (Talibi et al., 2014).

Screening of new microorganisms for use as biological control agents against postharvest diseases is a difficult process (Köhl et al., 2011). The selection of antagonistic yeasts from among the yeasts already present as resident in fruits can reduce the chance of failure, mainly due their natural adaptation to this environment, especially when compared with antagonists casually deposited on the plant surface or in the soil. Nevertheless, the selection of antagonist microorganisms should take into consideration that it must be genetically stable, have no complex nutrient requirements, be efficient at low population levels, be able to survive for long time periods under different 
environmental conditions, be effective in the control different pathogen species in different plant species, be able to grow in simple culture media, be easy to inoculate in the substrate, not produce dangerous substances to the host plant or to the human consumer, be resistant industrial processing procedures, not grow at $37^{\circ} \mathrm{C}$, and not be associated with disease in humans, other animals or the host plant (Sharma \& Awasthi, 2010).

Since the middle of the 20th century, several lineages of antagonist yeasts have been evaluated and used as efficient biocontrol agents of postharvest diseases of fruits and plants (Meng et al., 2010; Manso \& Nunes, 2011). Normally, the more frequent mechanisms related to the yeasts' capacity to control phytopathogens are competition for space and nutrients, mycoparasitism, induction of plant resistance, predation, and oxidative response (Pimenta et al., 2010; Zhang et al., 2017).

Several yeasts, such as Candida oleophila Montrocher 1967, Candida sake (Saito \& M. Ota) Uden \& H.R. Buckley ex S.A. Mey. \& Ahearn 1983, and Cryptococcus albidus (Saito) C.E. Skinner 1950 have been commercialized as biocontrol agents of postharvest diseases in the United States of America, Israel, South Africa, and Europe (Chen et al., 2012).

The present study aims to contribute to knowledge of the epiphytic yeast community associated with the Cerrado native tree Eugenia dysenterica (Mart.) DC. and to evaluate the possibility that these microorganisms synthetize metabolites with antimicrobial activity.

\section{MATERIALS AND METHODS}

Ripe and healthy fruits of $E$. dysenterica were collected randomly from 15 plants in October 2011, from the Fazenda Suécia ranch near to Porto Nacional, Tocantins, Brazil (10 68' S; $48^{\circ} 37^{\prime} \mathrm{W}$ ). The material was herborized and identification was made using identification keys and comparison with exicates in the UFT herbarium (HTO9571). The fruits were aseptically collected, placed in sterile plastic bags, and transported to the Laboratory of Environmental Microbiology and Biotechnology of the Federal University of Tocantins where they were immediately processed.

The fruit samples were immersed in $0.85 \%$ saline solution and shaken at $75 \mathrm{rpm}$ for $3 \mathrm{~min}$. The solution was discarded, and new $0.85 \%$ saline solution was added. The samples were then sonicated at an ultrasonic bath for $1 \mathrm{~min} .100 \mu \mathrm{l}$ of the solution were plated in Petri dishes with Nutrient Yeast Dextrose Agar medium (NYDA) (0.3\% Meat extract, $0.5 \%$ Yeast extract, $0.5 \%$ Peptone, $1 \%$ Glycose, and $2 \%$ Agar) and incubated at $25-28{ }^{\circ} \mathrm{C}$ for 48 hours (Janisiewicz et al., 2010). Three plates were used per each fruit.

The identification of yeasts was done through morphological and physiological criteria. All isolated yeasts were identified with taxonomic keys (Kurtzman et al., 2011). Reproductive characteristics, sexual spores formation, physiological and biochemical profiles through the fermentative and assimilative capacity of different carbon sources were analysed.

The isolated yeasts were stored in cryogenic vials with GYMP medium (0.1\% Yeast extract, 0.5\% Peptone, 1\% Glycose, and 0.02\% Monobasic Sodium Phosphate) supplemented with $15 \%$ glycerol, at $-80{ }^{\circ} \mathrm{C}$ in the microorganism collection of the Laboratory of General and Applied Microbiology of the Universidade Federal do Tocantins.

The evaluation of observed richness was performed using species data and the richness estimator Jackknife 1 available with EstimateS version 8.20 for Windows (Colwell, 2009). In order to prove the sufficiency of sampling, a species accumulation curve was produced per collected plant using Mao-Tau values with 200 randomizations, also with EstimateS software.

In order to perform antagonism essays, all isolated epiphytic yeasts were tested for diffusible substances against Aspergillus parasiticus Speare 1912 (IMI 2426989), provided by the International Mycological Institute, Colletotrichum gloeosporioides (Penz.) Penz. \& Sacc. 1884 (CG - INCOPER 02), and Monilinia fructicola (G. Winter)
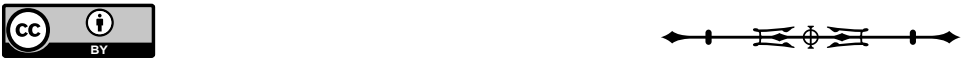
Honey 1928 (MFA 3635). The yeasts were transferred to a new plate with NYDA medium, inoculated linearly on one side of the plate, and incubated at $25-28^{\circ} \mathrm{C}$ for 48 hours. A 6 mm diameter agar disk with each phytopathogen mycelium was inoculated by the side of the yeasts inoculum, and the plates were incubated at $25-28^{\circ} \mathrm{C}$ for 72 hours. The yeasts' efficiency to control phytopathogen growth was classified as $(A)=$ no inhibition, $(B)=$ no growth inhibition but with sporulation inhibition, and $(\mathrm{C})=$ growth inhibition. A negative control was prepared with a phytopathogen fragment inoculated alone in NYDA plates. The epiphytic yeasts were considered phytopathogen antagonists when they inhibited $50 \%$ or more of the phytopathogen mycelium growth.

\section{RESULTS}

Forty-five inoculated plates were obtained from plating the 15 E. dysenterica aqueous fruit solutions. After selection, isolation, and purification, 42 epiphytic yeasts were obtained. These epiphytic yeasts were grouped in 11 species (Table 1) according to taxonomic keys (Kurtzman et al. , 2011) and were considered to have ascomycete affinity since none of them reacted to DBB (Diazonium Blue B).
Considering species richness increase per sampled plant, it is possible to observe continuous increase in yeast species number with increrasing sample size, approaching a stability (straight line)and curve stabilization (Figure 1).

All 42 epiphytic yeasts obtained were used for direct antagonism essays against the phytopathogens $A$. parasiticus, C. gloeosporioides and M. fructicola. Only 4 yeasts [Candida xylopsoci Kurtzman 2001 (isolates 17 and 18), C. sake (isolate 23), and Saccharomycopsis crataegensis Kurtzman \& Wick. 1973 (isolate 33)] were able to inhibit sporulation of $A$. parasiticus. The remaining 38 epiphytic yeasts were unable to inhibit or to reduce mycelium growth of any other tested phytopathogen (Table 2).

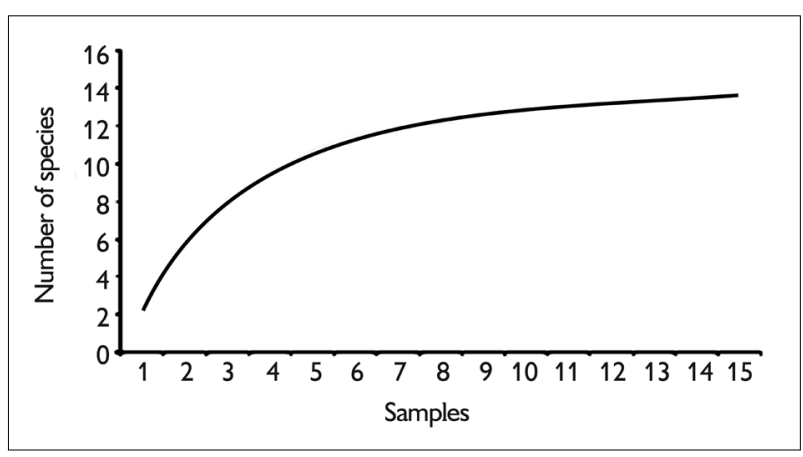

Figure 1. Yeast species richness curve per plant estimated with Jackknife 1 (software EstimateS) for E. dysenterica.

Table 1. Identified epiphytic yeasts isolated from E. dysenterica fruits.

\begin{tabular}{c|c|c}
\hline N & Species & Number of isolates \\
\hline 1 & Candida boidinii C. Ramirez 1953 & 2 \\
2 & Candida oleophila Montrocher 1967 & 1 \\
3 & Candida sake (Saito \& M. Ota) Uden \& H.R. Buckley ex S.A. Mey. \& Ahearn 1983 & 9 \\
4 & Candida xylopsoci Kurtzman 2001 & 11 \\
5 & Candida vartiovaarae (Capr.) Uden \& H.R. Buckley 1983 & 2 \\
6 & Candida wyomingensis Kurtzman 2000 & 3 \\
7 & Hgataea dorogensis (G. Péter, Tornai-Leh., Fülöp \& Dlauchy) Nagats., S. Saito \& Sugiy. 2008 & 5 \\
10 & Pichia membranifaciens (E.C.Hansen) E.C. Hansen 1904 & 1 \\
11 & Saccharomycopsis crataegensis Kurtzman \& Wick. 1973 & 1 \\
\hline
\end{tabular}

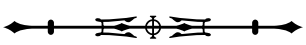


Table 2. Antagonism essays for diffusible substances with all the epiphytic yeasts isolated from $E$. dysenterica fruits against phytopathogens Aspergillus parasiticus, Colletotrichum gloeosporioides and Monilinia fructicola. Legends: $\mathrm{A}=$ no inhibition; $\mathrm{B}=$ no growth inhibition but with sporulation inhibition.

\begin{tabular}{c|c|c|c|c|c|c|c}
\hline Isolated yeasts & $\begin{array}{c}\text { Aspergillus } \\
\text { parasiticus }\end{array}$ & $\begin{array}{c}\text { Colletotrichum } \\
\text { gloeosporioides }\end{array}$ & $\begin{array}{c}\text { Monilinia } \\
\text { fructicola }\end{array}$ & Isolated yeasts & $\begin{array}{c}\text { Aspergillus } \\
\text { parasiticus }\end{array}$ & $\begin{array}{c}\text { Colletotrichum } \\
\text { gloeosporioides }\end{array}$ & $\begin{array}{c}\text { Monilinia } \\
\text { fructicola }\end{array}$ \\
\hline 1 & A & A & A & 22 & A & A & A \\
2 & A & A & A & 23 & B & A & A \\
3 & A & A & A & 24 & A & A & A \\
4 & A & A & A & 25 & A & A & A \\
5 & A & A & A & 26 & A & A & A \\
6 & A & A & A & 27 & A & A & A \\
7 & A & A & A & 28 & A & A & A \\
8 & A & A & A & 29 & A & A & A \\
9 & A & A & A & 30 & A & A & A \\
10 & A & A & A & 31 & A & A & A \\
11 & A & A & A & 32 & A & A & A \\
12 & A & A & A & 33 & B & A & A \\
13 & A & A & A & 34 & A & A & A \\
14 & A & A & A & 35 & A & A & A \\
15 & A & A & A & 36 & A & A & A \\
16 & A & A & A & 37 & A & A & A \\
17 & B & A & A & 38 & A & A & A \\
18 & B & A & A & 39 & A & A & A \\
19 & A & A & A & 40 & A & A & A \\
20 & A & A & A & 41 & A & A & A \\
21 & A & A & A & 42 & A & A & A \\
\hline
\end{tabular}

\section{DISCUSSION}

In the present study, 42 epiphytic yeasts were isolated from 45 inoculated plates with $E$. dysenterica aqueous fruit solutions. From these isolated yeasts, it was possible to identify 11 yeast species (Table 1) with ascomycete affinity, according to taxonomic keys (Kurtzman et al., 2011). In a study of yeast communities associated to fruits, mushrooms, tree exudates, and Drosophila fruit flies, in two places of the Atlantic Forest of Minas Gerais, Brazil, 608 strains were identified as belonging to the genus Candida, Cryptococcus, Debaryomyces, Galactomyces, Geotrichum, Issatchenkia, Kloeckera, Kodamaea, Metschnikowia, Myxozyma, Pichia,
Pseudozyma, Saccharomyces, Saccharomycopsis, Torulaspora and Zygoascos (Pimenta et al., 2009). Even considering all the different characteristics related with the ecosystems and host plants, it is notable that in both studies the same 3 yeast species (C. boidinii, P. membranifasciens and $S$. crataegensis) were isolated from fruits. Surprisingly, the only other published report on yeast species isolated from the Cerrado native $E$. dysenterica fruits do not share a single yeast species with the present study. The 9 isolated yeast species were identified as belonging to the genera Pseudozyma and Aureobasidium (Sperandio et al., 2015). This may be explained by the geographical and 
environmental differences between the three collection locations (Fazenda Suécia, Tocantins; Olympic Center of the University of Brasília, Federal District and National Park of Brasilia, Federal District), even if all of them are included in the Cerrado biome.

The species richness curve showed a proportional increase in species number and sample size, approaching as asymptote and curve stabilization (Figure 1). This suggests that the methodology used in this study was effective in isolating and identifying the yeast species present in E. dysenterica, which was confirmed with the richness estimator Jackknife 1 (Figure 1). Furthermore, the number of yeast species that may be found in fruits is significantly larger than the ones that may be found in other plant tissues, due to the higher nutritional value of the fruits. The species richness curve shows a stabilization tendency even with a small number of identified species because the methodology employed discarded all the transitory microbiota, leaving only the microbiota intimately associated with $E$. dysenterica fruits.

In this study, only 4 (two C. xylopsoci, one C. sake, and one $S$ crataegensis) of the 42 isolated epiphytic yeasts inhibited sporulation of $A$. parasiticus and none were effective against $C$. gloeosporioides and $M$. fructicola (Table 2). As far as known, this is the first report of sporulation inhibition in A. parasiticus by C. xylopsoci, C. sake, and $S$ crataegensis. However, a study using Saccharomyces sp. isolated from "ragi", a food ingredient traditionally used in Indonesia and usually composed of mixtures of moulds and yeasts, was able to significantly inhibit $A$. parasiticus growth, as shown by the decrease in mould growth, smaller vesicles, and lower number of phyallids (Dewanti-Hariyadi et al., 2014). This result was reinforced by another report demonstrating the antagonistic effects of Saccharomyces cerevisiae Meyen ex E.C. Hansen 1883 on the growth of $A$. parasiticus (Persons et al., 2013). Moreover, a similar result to the present study reported an $A$. parasiticus sporulation inhibition, but did not interfere in the mycelium growth, using Debaryomyces hansenii (Zopf) Lodder \& Kreger 1984 and Pichia anomala (E.C. Hansen) Kurtzman 1984 as fungi antagonists. The $D$. hansenii isolated yeasts were more effective, inhibiting in average $32 \%$ of sporulation while $P$. anomala inhibited in average 27\% (Ramos et al., 2010). Considering that phytopathogen sporulation reduction is a significant issue in control of fruit postharvest diseases and shelf-life extended time, then $C$. xylopsoci, C. sake, and S. crataegensis isolates may, in the future, be used in biological control protocols against A. parasiticus.

\section{CONCLUSION}

The present study contributes to the characterization and identification of epiphytic yeasts in E. dysenterica fruits. Additionally, this is the first report of in vitro A. parasiticus sporulation inhibition by C. xylopsoci, C. sake, and $S$ crataegensis. However, A. parasiticus mycelium growth was not affected, neither was $C$. gloeosporioides and $M$. fructicola sporulation or mycelium growth, by any of the 42 isolated epiphytic yeasts. Finally, C. xylopsoci, C. sake, and $\mathrm{S}$. crataegensis belong to a group of epiphytic yeasts with promise for use in future biological control of fruit phytopathogens.

\section{ACKNOWLEDGEMENTS}

The authors would like to thank C. M. Coelho and M. R. M. Oliveira for their personal collaboration. This study was supported by the Coordenação de Aperfeiçoamento de Pessoal de Nível Superior (CAPES) (AUXPE-PROAMAZONIA-3312/2013/process n. 23038.010315/201366). The authors also would like to acknowledge the Institutional Research Productivity Program (PROPESQ/ UFT) of the Federal University of Tocantins.

\section{REFERENCES}

AGLER, M. T., J. RUHE, S. KROLL, C. MORHENN, S. T. KIM, D. WEIGEL \& E. M. KEMEN, 2016. Microbial hub taxa link host and abiotic factors to plant microbiome variation. PLoS Biology 14(1): e1002352. DOI: https://doi.org/10.1371/journal.pbio.1002352. 
BARRIGA, E. I. C., P. P. BARAHONA, C. TUFIÑO, B. BASTIDAS, C. GUAMÁN-BURNEO, L. FREITAS \& C. ROSA, 2014. An overview of the yeast biodiversity in the Galápagos islands and other Ecuadorian regions. In: O. GRILLO (Ed.): Biodiversity - The dynamic balance of the planet: 193-232. InTech, Rijeka. DOI: https://doi.org/10.5772/58303.

BERG, G., M. GRUBE, M. SCHLOTER \& K. SMALLA, 2014. Unravelling the plant microbiome: looking back and future perspectives. Frontiers in Microbiology 5: 148. DOI: https://doi. org/10.3389/fmicb.2014.00148.

CHEN, X., J. LI, L. ZHANG, X. XU, A. WANG \& Y. YANG, 2012. Control of postharvest radish decay using a Cryptococcus albidus yeast coating formulation. Crop Protection 41: 88-95. DOI: https://doi. org/10.1016/j.cropro.2012.05.015.

CHOMNUNTI, P., S. HONGSANAN, B. AGUIRRE-HUDSON, Q. TIAN, D. PERSOH, M. K. DHAMI, A. S. ALIAS, J. XU, X. LIU, M. STADLER \& K. D. HYDE, 2014. The sooty moulds. Fungal Diversity 66(1): 1-36. DOI: https://doi.org/10.1007/s13225-014-0278-5.

COLWELL, R. K., 2009. EstimateS: Statistical estimation of species richness and shared species from samples. Ver. 8.2. University of Connecticut, Storrs, Connecticut. Available at: http://viceroy.eeb. uconn.edu/estimates. Accessed on: 23 mar 2014.

DEWANTI-HARIYADI, R., D. S. RAHARJANTI, C. C. NURWITRI \& E. KUSUMANINGTYAS, 2014. Inhibition of Aspergillus parasiticus growth and reduction of aflatoxin by yeast isolated from Ragi, an Indonesian traditional culture starter. In: L. NURAIDA, P. HARIYADI, R. DEWANTI-HARIYADI, H. D. KUSUMANINGRUM, D. G. PRATIWI \& N. IMMANINGSIH (Ed.): Investing in food quality safety \& nutrition: 211-224. Southeast Asian Food \& Agricultural Science \& Technology (SEAFAST) Center, Bogor Agricultural University, Bogor, Indonesia.

GRONDIN, E., A. S. C. SING, Y. CARO, M. RAHERIMANDIMBY, A. L. RANDRIANIERENANA, S. JAMES, C. NUENO-PALOP, J. M. FRANÇOIS \& T. PETIT, 2015. A comparative study on the potential of epiphytic yeasts isolated from tropical fruits to produce flavouring compounds. International Journal of Food Microbiology 203: 101-108. DOI: https://doi.org/10.1016/j.ijfoodmicro.2015.02.032.

HANSEN, A. K. \& N. A. MORAN, 2014. The impact of microbial symbionts on host plant utilization by herbivorous insects. Molecular Ecology 23(6): 1473-1496. DOI: https://doi.org/10.1111/mec.12421.

HONGSANAN, S., Y. M. LI, J. K. LIU, T. HOFMANN, M. PIEPENBRING, J. D. BHAT, S. BOONMEE, M. DOILOM, C. SINGTRIPOP, Q. TIAN, A. MAPOOK, X. Y. ZENG, A. H. BAHKALI, J. C. XU, P. E. MORTIMER, X. H. WU, J. B. YANG \& K. D. HYDE, 2014. Revision of genera in Asterinales. Fungal Diversity 68(1): 1-68. DOI: https://doi.org/10.1007/s13225-014-0307-4.
HONGSANAN, S., Q. TIAN, D. PERSON, X. Y. ZENG, K. D. HYDE, P. CHOMNUNTI, S. BOONMEE, A. L. BAHKALI \& T. C. WEN, 2015a. Meliolales. Fungal Diversity 74(1): 1-51. DOI: https:// doi.org/10.1007/s13225-015-0344-7.

HONGSANAN, S., Q. TIAN, A. H. BAHKALI, J. B. YANG, E. H. C. MCKENZIE, P. CHOMNUNTI \& K. D. HYDE, 2015b. Zeloasperisporiales ord. nov., and two new species of Zeloasperisporium. Cryptogamie, Mycologie 36(3): 301-317. DOI: https://doi.org/10.7872/crym/v36.iss3.2015.301.

HOGSANAN, S., K. D. HYDE, A. H. BAHKALI, E. CAMPORESI, P. CHOMNUNTI, H. EKANAYAKA, A. A. M. GOMES, V. HOFSTETTER, E. B. G. JONES, D. B. PINHO, O. L. PEREIRA, Q. TIAN, D. N. WANASINGHE, J. C. XU \& B. BUYCK, 2015c. Fungal biodiversity profiles 11-20. Cryptogamie, Mycologie 36(3): 355-380. DOI: https://doi.org/10.7872/crym/v36.iss3.2015.355.

HONGSANAN, S., S. SÁNCHEZ-RAMIREZ, P. W. CROUS, H. A. ARIYWANSA, R. L. ZHAO \& K. D. HYDE, 2016. The evolution of fungal epiphytes. Mycosphere 7(11): 1690-1712. DOI: https://doi. org/10.5943/mycosphere/7/11/6.

HYDE, K. D., E. B. G. JONES, J. K. LIU, H. ARIYAWANSA, E. BOEHM, S. BOONMEE, U. BRAUN, P. CHOMNUNTI, P. W. CROUS, D. Q. DAI, P. DIEDERICH, A. DISSANAYAKE, M. DOILOM, F. DOVERI, S. HONGSANAN, R. JAYAWARDENA, J. D. LAWREY, Y. M. LI, Y. X. LIU, R. LÜCKING, J. MONKAI, L. MUGGIA. M. P. NELSEN, K. L. PANG, R. PHOOKAMSAK, I. C. SENANAYAKE, C. A. SHEARER, S. SUETRONG, K. TANAKA, K. M. THAMBUGALA, N. L. WIJAYAWARDENE, S. WIKEE, H. X. WU, Y. ZHANG, B. AGUIRRE-HUDSON, S. A. ALIAS, A. APTROOT, A. H. BAHKALI, J. L. BEZERRA, D. J. BHAT, E. CAMPORESI, E. CHUKEATIROTE, C. GUEIDAN, D. L. HAWKSWORTH, K. HIRAYAMA, S. DE HOOG, J. C. KANG, K. KNUDSEN, W. J. LI, X. H. LI, Z. Y. LIU, A. MAPOOK, E. H. C. MCKENZIE, A. N. MILLER, P. E. MORTIMER, A. J. L. PHILLIPS, H. A. RAJA, C. SCHEUER, F. SCHUMM, J. E. TAYLOR, Q. TIAN, S. TIBPROMMA, D. N. WANASINGHE, Y. WANG, J. C. XU, S. YACHAROEN, J. Y. YAN \& M. ZHANG, 2013. Families of Dothideomycetes. Fungal Diversity 63(1): 1-313. DOI: https://doi.org/10.1007/s13225-013-0263-4.

JANISIEWICZ, W. J., C. P. KURTZMAN \& J. S. BUYER, 2010. Yeasts associated with nectarines and their potential for biological control of brown rot. Yeast 27(7): 389-398. DOI: https://doi.org/10.1002/ yea.1763.

KÖHL, J., J. POSTMA, P. NICOT, M. RUOCCO \& B. BLUM, 2011. Stepwise screening of microorganisms for commercial use in biological control of plant-pathogenic fungi and bacteria. Biological Control 57(1): 1-12. DOI: https://doi.org/10.1016/j. biocontrol.2010.12.004.

KURTZMAN, C. P., J. W. FELL \& T. BOEKHOUT, 2011. The yeasts: a taxonomic study: 5. ed.: 1-2354. Elsevier Science, Amsterdam.

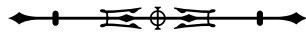


LI, G. J., K. D. HYDE, R. L. ZHAO, S. HONGSANAN, F. A. ABDEL-AZIZ, M. A. ABDEL-WAHAB, P. ALVARADO, G. ALVESSILVA, J. F. AMMIRATI, H. A. ARIYAWANSA, A. BAGHELA, A. H. BAHKALI, M. BEUG, D. J. BHAT, D. BOJANTCHEV, T. BOONPRATUANG, T. S. BULGAKOV, E. CAMPORESI, M. C. BORO, O. CESKA, D. CHAKRABORTY, J. J. CHEN, K. W. T. CHETHANA, P. CHOMNUNTI, G. CONSIGLIO, B. K. CUI, D. Q. DAI, Y. C. DAI, D. A. DARANAGAMA, K. DAS, M. C. DAYARATHNE, E. DE CROP, R. J. V. DE OLIVEIRA, C. A. F. DE SOUZA, J. I. DE SOUZA, B. T. M. DENTINGER, A. J. DISSANAYAKE, M. DOILOM, E. R. DRECHSLER-SANTOS, M. GHOBAD-NEJHAD, S. P. GILMORE \& A. GÓES-NETO, 2016. Fungal diversity notes 253-366: taxonomic and phylogenetic contributions to fungal taxa. Fungal Diversity 78(1): 1-237. DOI: https://doi.org/10.1007/s13225-016-0366-9.

LUDWIG-MÜLLER, J., 2015. Bacteria and fungi controlling plant growth by manipulating auxin: balance between development and defense. Journal of Plant Physiology 172: 4-12. DOI: https://doi. org/10.1016/j.jplph.2014.01.002.

LUGTENBERG, B., D. E. ROZEN \& F. KAMILOVA, 2017. Wars between microbes on roots and fruits. F1000 Research 6: 343. DOI: https://doi.org/10.12688/f1000research.10696.1.

MAHAMUNI, S. V., N. S. SHINDE, P. V. WANI \& A. S. PATIL, 2017. Antifungal appraisal of Burkholderia gladioli strain VIMP03 (JQ867372) against Ceratocystis paradoxa. Asian Journal of Pharmaceutical and Clinical Research 10(3): 221-226. DOI: https://doi.org/10.22159/ajpcr.2017.v10i3.16080.

MANSO, T. \& C. NUNES, 2011. Metschnikowia andauensis as a new biocontrol agent of fruit postharvest diseases. Postharvest Biology and Technology 61(1): 64-71. DOI: https://doi.org/10.1016/j. postharvbio.2011.02.004.

MENG, X. H., G. Z. QIN \& S. P. TIAN, 2010. Influences of preharvest spraying Cryptococcus laurentii combined with postharvest chitosan coating on postharvest diseases and quality of table grapes in storage. LWT - Food Science and Technology 43(4): 596-601. DOI: https://doi.org/10.1016/j.lwt.2009.10.007.

NEWMAN, D. J. \& G. M. CRAGG, 2015. Endophytic and epiphytic microbes as "sources" of bioactive agents. Frontiers in Chemistry 3: 34. DOI: https://doi.org/10.3389/fchem.2015.00034.

NISA, H., A. N. KAMILI, I. A. NAWCHOO, S. SHAFI, N. SHAMEEM \& S. A. BANDH, 2015. Fungal endophytes as prolific source of phytochemicals and other bioactive natural products: a review. Microbial Pathogenesis 82: 50-59. DOI: https://doi. org/10.1016/j.micpath.2015.04.001.

PANKE-BUISSE, K., A. C. POOLE, J. K. GOODRICH, R. E. LEY \& J. KAO-KNIFFIN, 2015. Selection on soil microbiome reveals reproducible impacts on plant function. The ISME Journal 9: 980-989.
PARTIDA-MARTÍNEZ, L. P. \& M. HEIL, 2011. The microbe-free plant: fact or artefact? Frontiers in Plant Science 2: 100. DOI: https:// doi.org/10.3389/fpls.2011.00100.

PERSONS, K., J. M. RAINES \& J. M. RODRIGUEZ, 2013. Antagonistic effects of Saccharomyces cerevisae on the growth of Aspergillus flavus and Aspergillus parasiticus at varying temperatures. Mycology 4(1): 38-43. DOI: https://doi.org/10.1080/21501203.20 12.754796 .

PIMENTA, R. S., P. D. D. ALVES, G. M. F. ALMEIDA, J. F. M. SILVA, P. B. MORAIS, A. CORRÊA JR. \& C. A. ROSA, 2009. Yeast communities in two Atlantic rain forest fragments in Southeast Brazil. Brazilian Journal of Microbiology 40(1): 90-95. DOI: http://dx.doi. org/10.1590/S1517-83822009000100015.

PIMENTA, R. S., J. F. M. SILVA, C. M. COELHO, P. B. MORAIS, C. A. ROSA \& A. CORRÊA JR., 2010. Integrated control of Penicillium digitatum by the predacious yeast Saccharomycopsis crataegensis and sodium bicarbonate on oranges. Brazilian Journal of Microbiology 41(2): 404-410. DOI: http://dx.doi.org/10.1590/ S1517-83822010000200022.

RAMOS, D. M. B., C. F. SILVA, L. R. BATISTA \& R. F. SCHWAN, 2010. Inibição in vitro de fungos toxigênicos por Pichia sp. e Debaryomyces sp. isoladas de frutos de café (Coffea arábica). Acta Scientiarum Agronomy 32(3): 397-402. DOI: http://dx.doi. org/10.4025/actasciagron.v32i3.3361.

SCHOCH, C. L., P. W. CROUS, J. Z. GROENEWALD, E. W. BOEHM, T. I. BURGESS, J. DE GRUYTER, G. S. DE HOOG, L. I. DIXON, M. GRUBE, C. GUEIDAN, Y. HARADA, S. HATAKEYAMA, K. HIRAYAMA, T. HOSOYA, S. M. HUHNDORF, K. D. HYDE, E. B. JONES, J. KOHLMEYER, A. KRUYS, Y. M. LI, R. LÜCKING, H. T. LUMBSCH, L. MARVANOVÁ, J. S. MBATCHOU, A. H. MCVAY, A. N. MILLER, G. K. MUGAMBI, L. MUGGIA, M. P. NELSEN, P. NELSON, C. A. OWENSBY, A. J. PHILLIPS, S. PHONGPAICHIT, S. B. POINTING, V. PUJADE-RENAUD, H. A. RAJA, E. R. PLATA, B. ROBBERTSE, C. RUIBAL, J. SAKAYAROJ, T. SANO, L. SELBMANN, C. A. SHEARER, T. SHIROUZU, B. SLIPPERS, S. SUETRONG, K. TANAKA, B. VOLKMANN-KOHLMEYER, M. J. WINGFIELD, A. R. WOOD, J. H. WOUDENBERG, H. YONEZAWA, Y. ZHANG \&J. W. SPATAFORA, 2009. A class-wide phylogenetic assessment of Dothideomycetes. Studies in Mycology 64(S10): 1-15. DOI: https:// doi.org/10.3114/sim.2009.64.01.

SHARMA, N. \& P. AWASTHI, 2010. Postharvest technology-yeast as biocontrol agents: progress, problems and prospects. In: A. ARYA \& A. E. PERELLÓ (Ed.): Management of fungal plant pathogens: 109-120. CAB International, Preston, UK.

SPERANDIO, E. M., H. M. MARTINS DO VALE \& G. A. M. MOREIRA, 2015. Yeasts from native Brazilian Cerrado plants: occurrence, diversity and use in the biocontrol of citrus green mould. Fungal Biology 119(11): 984-993. DOI: https://doi.org/10.1016/j. funbio.2015.06.011.

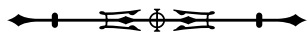


STANTON, D. E., J. H. CHÁVEZ, L. VILLEGAS, F. VILLASANTE, J. ARMESTO, L. O. HEDIN \& H. HORN, 2014. Epiphytes improve host plant water use by microenvironment modification. Functional Ecology 28(5): 1274-1283. DOI: https://doi.org/10.1111/13652435.12249.

TALIBI, I., H. BOUBAKER, E. H. BOUDYACH \&A. A. B. AOUMAR, 2014. Alternative methods for the control of postharvest citrus diseases. Journal of Applied Microbiology 117(1): 1-17. DOI: https:// doi.org/10.1111/jam.12495.

VAN LENTEREN, J. C., K. BOLCKMANS, J. KÖHL, W. J. RAVENSBERG \& A. URBANEJA, 2018. Biological control using invertebrates and microorganisms: plenty of new opportunities. BioControl 63(1): 39-59. DOI: https://doi.org/10.1007/s10526017-9801-4.
WU, H. X., C. L. SCHOCH, S. BOONMEE, A. H. BAHKALI, P. CHOMNUNTI \& K. D. HYDE, 2011. A reappraisal of Microthyriaceae. Fungal Diversity 51(1): 189-248. DOI: https:// doi.org/10.1007/s13225-011-0143-8.

ZHANG, H., L. CHEN, Y. SUN, L. ZHAO, X. ZHENG, Q. YANG \& X. ZHANG, 2017. Investigating proteome and transcriptome defense response of apples induced by Yarrowia lipolytica. Molecular Plant-Microbe Interactions 30(4): 301-311. DOI: https://doi. org/10.1094/MPMI-09-16-0189-R. 
